\title{
In Memoriam: Arthur F. Southwick and Dieter Giesen
}

The editors of the American Journal of Law \& Medicine, on behalf of the American Society of Law, Medicine \& Ethics and Boston University School of Law, regret to announce the deaths of Professor Arthur F. Southwick, of the University of Michigan Graduate School of Business Administration, and Professor Doctor Dieter Giesen, of The Free University Berlin Institute for International, Foreign and Comparative Law and Director of the Working Centre for International Studies in Medical Malpractice Law. Both Professor Southwick and Dr. Giesen passed away earlier this year. Professor Southwick and Dr. Giesen were long-time editors of the American Journal of Law \& Medicine and served occasionally as peer reviewers of papers submitted to the Journal of Law, Medicine \& Ethics.

The editors will greatly miss their editorial advice. 
VANDERBLIT UNIVERSITY SCHOOL OF MEDICINE

and

American Society of Law, Medicine \& Ethics and

American Academy of Pediatrics

with

American Association of Critical Care Nurses

and

Association for the Care of Children's Health

present

\section{Children, Parents, Professionals, AND THE STATE: \\ Who ChOOSES for the ChILD?}

\section{September 19-20, 1997}

\section{Cambridge, Massachusetts}

Vanderbilt University School of Medicine is accredited by ACCME to sponsor CME for physicians. Vanderbilt University School of Medicine designates this educational activity for a maximum of 14 credit hours in Category I of the AMA physicians's Recognition Award. CLE and CNE credit pending.

St. John's Health System and American Society of Law, Medicine \& Ethics in cooperation with

Midwest Bioethics Center and Missouri Hospital Association present

\section{Taking Responsibility for Effective Pain Management: Professional, Institutional \& Legal Strategies}

Springfield-Branson, Missouri November 14-16, 1997

Who Should Attend:

- Physicians, nurses, psychologists, therapists, and social workers responsible for patient care

- Health care regulators

- Health insurers, administrators, and medical staff leadership

Call 617-262-4990 for a brochure by mail or fax 